\title{
Relevant Correlations among Reputation, WOM and e-WOM with Satisfaction of Distance Education
}

\author{
Osama Ahmed Abdelkader \\ Associate Professorof Marketing, Department of Marketing, \\ College of Applied Studies and Community Service, University of Dammam, \\ 4049 - as safa , Unit No.: 1, AD DAMMAM 34221-7842, Kingdom of \\ Saudi Arabia. E-mail: osamamarketing@gmail.com
}

\begin{abstract}
This paper aimed to test the relevant correlations among Word-Of-Mouth, electronic-Word-Of-Mouth e-WOM, reputation and satisfaction of distance education. Also, the study explored a set of key elements of the service with regard to satisfaction of distance education, including: curricula, instructors, procedures, customer value and equipment.Finally, the paper analyzed the differences of satisfaction extent according togender, age and nationality. The findings indicated significant factors influence satisfaction and reputation, and estimated the weight of each factor. The study presented a proposed modelto assist practitioners and researchers who are interested in activities that combine computer work with education performance and stakeholder satisfaction. The proposed model was applied on Saudi Arabia, and the sample was collected from the distance education students of Dammam University. More generalizations could be developed, based on these findings, when conducting further research on other universities, countries and cultures.

Keywords: Marketing, Distance Education, Customer Satisfaction, Reputation, WOM, e-WOM

\section{Introduction}

Increasingly, world universities are depending on distance education. A basic key success of any technology is the satisfaction extent of its users. The valuation of education service does not depend on technical quality alone. One way or another, humans are affected by Word-Of-Mouth WOM from others and reputation, when they valuate any service. Therefore, Distance Education (DE) has become a common way to present education programs as opposed to traditionalprograms (Bower et al, 2015;
\end{abstract}


MalganovaandRahkimova, 2015). DE is becoming a major mode of teaching and learning (Latypovand Sabirova, 2016). The tools of DE offer new interactivealternatives for students to learn, which may alleviate the drop-out rate problem (Berberoğlu, 2015). An assessment of this learning mode is important to evaluate the quality of learning and to provide useful directions for effective management of online education(Hone et al, 2016). The success of $\mathrm{DE}$ efforts requires three main pillars; technology, curricula and satisfaction of targeted audience.Therefore, relationships among quality dimensions in higher education should be studied and the effect of each quality dimension on satisfactionlevels should be assessed (Yilmaz et al., 2013; Ardi et al., 2012). Effective DE requires not only quality computer systems, but also high satisfaction and acceptable reputation among stakeholders (Poellhuber et al., 2013; Sandmaung and Khang, 2013; Sultan and Wong, 2012).The human aspect of DE is still in a relatively early stage of researchwith regard toexploring the extent to which students' wants and needs arebeing satisfied (Celikand Uzunboylu, 2015; O'Cass, and Ngo, 2011). IF user satisfaction is not taken into consideration, all efforts of DE may be useless. Therefore, this study focuses on explore factors influence student satisfaction about DE programs.

\section{Literature Review}

\subsection{Distance Education DE}

Today, hundreds of world universities present their programs by distance or a mix of distance learning with face-to-face, learning. Thousands of people find DE to be suitable way to gain knowledge or improve their job situations (Berberoğlu, 2015). DE has a great importance in meeting the needs of professionals and practitioners in various fields (Latypovand Sabirova, 2016; Bower et al, 2015;Brinson, 2015; Koper, 2015; Y1lmaz et al., 2013). Enrollment of DE is increasing rapidly in different countries to various types of institutions offeringa variety of scientific degrees (Korving et al, 2016) with a high level of academic achievements (Joksimović et al, 2015). A lot of channels, devicesand methods are used in DE (Sung et al, 2016; Bower et al, 2015; Van Rooyen, 2015) by tens of languages (York et al, 2016). DE is the future of education in all over the world (Malganovaand Rahkimova, 2015; Berberoğlu, 2015; Celikand Uzunboylu, 2015). However, the real challenge lies in determining the satisfaction level of DE users (Barak and Levenberg, 2016). Also, the responsibilities of teachers and administrators who implement DE exceed those of traditional education (Semradovaand Hubackova, 2016). 


\subsection{Satisfaction}

Satisfaction is defined as an effective state resulting from a judgment of performance compared to expectations (Mysen et al., 2011).ServicesOrganizations should take steps to determine satisfaction levels among their customers (Edward and Sahadev, 2011). The study of Barak and Levenberg, (2016) confirmed significant differences among people with reared to their acceptance of technologies. Literature of Merhi, (2015)refers to various factors which influence satisfaction: equipment (Mbati and Minnaar, 2015), service quality (Kaur, 2013) and customer value $(\mathrm{Wu}, 2011)$. Some of these previous studies indicated significant differences in satisfaction of DE according to age (Hone et al, 2016; SanMartín et al, 2015) and gender (Celikand Uzunboylu, 2015; Poellhuber et al., 2013).Present literature includes studies applied on manynationals: Canada (Poellhuber et al., 2013), India (Ganguli, and Roy, 2011), Egypt (Ali, 2010), Jordan (Oda, 2012), Philippine (Lorenzo-Molo, 2007), Turkey (Y1lmaz et al., 2013), South Africa (de Hart et al, 2015), Iraq (Aldulimi, 2014).

Research Question \#1 (RQ1): Do gender, age and nationality have a significant effect on student satisfaction of DE services? The answer ofthis question was covered in this study by three hypotheses as follows:

$\mathrm{H}_{1}$ : There are significant differences in satisfaction levels, according to gender

$\mathrm{H}_{2}$ : There are significant differences in satisfaction levels, according to age

$\mathrm{H}_{3}$ : Thereare significant differences in satisfaction levels, according to nationality

RQ2: What are the significant key elements of a DE service? This question was answered through the analysis of the following hypothesis:

$\mathrm{H}_{4}$ : There are significant correlations between reputation, curricula, instructors, equipment, customer value and procedures with satisfaction of DE service.

The study depended on three items to measure student satisfaction as follows:

$\mathrm{X}_{1}$. How well needs are met (Kaur, 2013; Ganguli, and Roy, 2011)

$\mathrm{X}_{2}$. Feeling happy with the decision they had made (Kaur, 2013; Liang and Zhang, 2012; Ganguli, and Roy, 2011; Edward and Sahadev, 2011)

$\mathrm{X}_{3}$. Overall Satisfaction (Liang and Zhang, 2012; Ganguli, and Roy, 2011; Edward and Sahadev, 2011) 
The following items were used in this study to measure thekey elements of DE service, which were suggested by Sandmaung and Khang, (2013); Y1lmaz et al., (2013) and Ardi et al., (2012):

Curricula Items:

$\mathrm{X}_{4}$. Acceptable level of ease

$\mathrm{X}_{5}$.Compatibility with scientific development

$\mathrm{X}_{6}$. Compatibility with labor market needs

$\mathrm{X}_{7}$.Compatibility with personalneeds

$\mathrm{X}_{8}$. Diversity of specialties

Teachers Items:

$\mathrm{X}_{9}$. Teaching methods

$\mathrm{X}_{10}$. Ethics of dealing with students

Procedures Items:

$\mathrm{X}_{11}$. Admission

$\mathrm{X}_{12}$. Registration

$\mathrm{X}_{13}$. Cancelation ofregistration

$\mathrm{X}_{14}$. Formal communications with officers \& employees

Customer Values Items:

$\mathrm{X}_{15}$. Comparison between the cost of the study \& its value

$\mathrm{X}_{16}$. Comparison to similar programs of other universities

Equipment Items:

$\mathrm{X}_{17}$. Website design

$\mathrm{X}_{18}$. Website contents

$\mathrm{X}_{19}$. Interactive lectures

$\mathrm{X}_{20}$. Communication with instructors

$\mathrm{X}_{21}$. Technical support

1.3 Reputation

Reputation is defined as the collective total of all previous transactions of a retailer over an extended period of time (Kim, and Lennon, 2013). It refers to common opinion and social evaluation that people have about someone or something. Good reputation may reduce buyers' price sensitivity (Biong, 2013) and enhance customer loyalty (Amin et al., 2013). Some studies pointed out positive relations between reputationand purchasing decision (Shim and Yang, 2015). Management of reputation is necessary for business (Men, 2012), for DE service or anyanother field. The public opinion about the reputation of any DE program or institute which presents it, may be different among people(Barak and Levenberg, 2016). Oda, (2012)indicated that the design of university-website influences its reputation. In the higher education context, a group of studies support that satisfaction positively 
affects university reputation(Saeidi et al, 2015; Tournois, 2015; Sultan and Wong, 2012), and many other studies confirmed a significant relation between them ( $\mathrm{Su}$ et al, 2016; Shin et al, 2015; Saeidi et al, 2015; Argan, 2016; Sengupta et al, 2015; Mulki, and Jaramillo, 2011).Reputation influences satisfaction indirectly through the impact of perceived value (Cretu and Brodie, 2007).

RQ3: Is the significant relation between a university's reputation and students' satisfaction of the DE program, it offers? The answer of this question is covered by the following hypothesis:

$\mathrm{H}_{5}$ : Reputation significantly influences satisfaction.

This study depended on two items to measure reputation as follows:

$\mathrm{X}_{22}$. University is well-known (Kimand Lennon, 2013)

$\mathrm{X}_{23}$. University has good reputation (Kimand Lennon, 2013)

\subsection{Word-Of-Mouth WOM}

WOM is informal advice (Huang et al., 2011) and oral communication(Abrantes et al., 2013) among people about something (e.g. services, products or any social issue). The findings ofLo'pez and Sicilia, (2013), Yang et al., (2012) and Huang et al., (2011) suggested that there are significant relations between WOM and product sales. There remain many unanswered questions with regard WOM which need to be further eresearched (Lang and Lawson, 2013). According to the Word of Mouth Marketing Association (2007), WOM Marketing is defined as giving people a reason to talk about your products and services, and making it easier for that conversation to take place. The effects of WOM may exceed those of promotion activities, therefore, it should be managed by individuals or organizations(Yang, 2016;Lo'pez and Sicilia, 2013;Ali, 2010). Usually, when people are satisfied, itpositively influences their $\mathrm{WOM}(\mathrm{Su}$ et al, 2016; Su et al, 2015).Thus, satisfaction influences positive WOM of customers (Liang and Zhang, 2012; Wu, 2011; Mulki, and Jaramillo, 2011). A set of studies confirmed the relation between WOM and reputation (Argan, 2016; Tournois, 2015; Casidyand Wymer, 2015). There is a need in the theory literature of WOM for contributions from researchers to cover a set of contemporary issues (Aldulimi, 2014; Abdelhameed and Alqasaby, 2012; Yang et al., 2012).

RQ4: Are the relations between WOM and reputation and satisfaction significant?The answer to this question is covered by the following hypotheses:

$\mathrm{H}_{6}$ : Satisfaction significantly influences WOM. 
$\mathrm{H}_{7}$ : WOM significantly influences reputation.

The following items were used in this study to measure WOM:

$\mathrm{X}_{24}$. Talking to others about the program (Liang and Zhang, 2012; Mulki, and Jaramillo, 2011).

$\mathrm{X}_{25}$. Providing information about the program (Abrantes et al., 2013).

1.5 Electronic Word-Of-Mouthe-WOM

There is a wide difference of opinion regarding technology uses (Barak and Levenberg, 2016). E-WOM refers to any statement consumers share via virtual community about a service or organization or any another thing (Bachledaand Berrada-Fathi, 2016; Abrantes et al., 2013).The internet media has shown to be more influential thanWOM (Sung et al, 2016; Bower et al, 2015). There are various shapes of e-WOM: one-to-one, many-to-many or one-to-many (Huang et al., 2011). Some literature refersto significantdifferences in the spread of e-WOM according togender (Kulmala et al., 2013), content (Aldulimi, 2014) and nationality (Christodoulides et al., 2012).Marketers should have enough knowledge about professional uses of internet to manage e-WOM successfully on various social media (Chen et al, 2016; Gura u, 2013; Lin, et al., 2012). The study of Changand Wu, (2014)confirmed that e-WOM has a positive impact on the success of corporations offering a service, and indicated that poor management for eWOM may lead to negative effects on brand commitment. Credibility, quality and usefulness of information may influence e-WOM,according to the conclusions of Erkanand Evans,(2016). Massive open online courses are affected by factors such as; age or level of study(Hone et al, 2016).People have two circles of e-WOMstrong ties and weak ties (Abrantes et al., 2013), and marketers should analyze both for among their targeted audience. DE administrators should differamong the sites of e-commerce and social media of design quality (Yan et al, 2016) or DE services (Van Rooyen, 2015), due to the importance(Kim, and Lennon, 2013).Marketers and managers of any human projectshould understand how to manage e-WOM (Kietzmann and Canhoto, 2013) to enhance their reputation of product, service or organization. Literature confirms that e-WOM influencespurchase decisions, product evaluations (Christodoulides et al., 2012), satisfaction and reputation (Chen et al, 2016). In the context of strong reputation building, satisfied customers spread positive words about a corporation and its employees or products (Su et al, 2016;Su et al, 2015; Saeidi et al, 2015). 
RQ5: Are the relations between e-WOM and reputation and satisfaction, significant? The answer of this question is covered by the following hypotheses:

$\mathrm{H}_{8}$ : Satisfaction significantly influences e-WOM.

$\mathrm{H}_{9}$ : e-WOM significantly influences reputation.

The following items were used in this study to measure e-WOM:

$\mathrm{X}_{26}$. Talking to others through social media about the program (Liang and Zhang, 2012; Mulki, and Jaramillo, 2011).

$\mathrm{X}_{27}$. Providing people with information through social media about the program (Abrantes et al., 2013).

In the context of such previous literature, this study aimed to investigate the significance of the relationships among WOM, e-WOMand Reputation with satisfaction about DE service, and to explore the significant differences of satisfaction levelsamong students of DE programs,based on their gender, age and nationality. These purposes should be considered by practitioners and researchers who are interested in computer works oreducation by distance.

\section{Method}

2.1Instrument Building procedures

This study was designed as a mixed-approach where qualitative and quantitative methods were used. A group of pilot interviews with experts and primary groups of participants were administered, acting as a qualitative approachin order to generate the indicators, while consideringthe literature review. The quantitative approach includes Confirmatory Factors Analysis CFA, Structural Equation Modeling SEM, Multi Regression Analysis MRA, and some statistical indices of model fit. The instrument of this research was represented in an "e-questionnaire" through "Google Drive"based on a fivepoint Likert-scale. It was built on a qualitative review approach.A multiresources approach was followed to test the validity and reliability of the instrument. This approach includes three groups of studies and tests to ensure that the instrument was valid and reliable, as follows:

2.1.1First, a group of pilot studies focused on generating the most important factors and items of the questionnaire. It contains three studies; (A) Literature review for related studies which was presented through the previous part of this paper. (B) Open discussion interviews were organized with seven experts in the field of DE, includingthree faculties, two administrators and two technical supporters. (C) A semi-structured interview was managed with 32 participants of the population based on open brainstorming(a large sample should be at least32 participants). The sample was collected to represent all 
ofthe eight levels of study in DE programs - two participates from each level, 16 females and 16 males.

2.1.2Second, two testsfocused on validity: (A) A review of a questionnaire byeight experts and academics, includingthe main fields:methodology, DE, statistical analysis and businessadministration. They suggested a set of modifications to be more valid. (B) An in-depth semi-structured interview was conducted with 48participants from the population to ensure that the questionnaire was clear, six-participants from each level, 24 females and 24 males. Some modifications were done to the questionnaire to enhance clarity.The questionnaire after validity test contained 9 factors including 27 items.

2.1.3Third, a group of post-tests focused on testing reliability,containing; Cronbach's Alpha, CFA, Kaiser-Meyer-Olki KMO (to ensure the efficiency of the sample size), Bartilett-of-Sphericity (to ensure the significance of correlations among variables of each factor) and Confidence Interval CI,Average Variances Extracted AVE, Composite Reliability CR and power of study.

\subsection{Population and Sampling}

There are 36 universities in Saudi Arabia(http://www.moe.gov.sa). Business administration programs are the most common DE programs in Saudi Arabia universities.Dammam university is one of institutions offering DE programs in Saudi Arabia, presentingjust a DE program of business administration. The population of this research consisted of the enrolled students in theDE programoffered at Dammam university by distance. The equestionnaire was distributed randomly to 640 students. The collected responses were 595 valid cases, that represented $92.97 \%$ of the sample. Table 1 shows the description of the sample as follows:

Table 1

Demographic information and characteristics of respondents

\begin{tabular}{cccc}
\hline Measure & Items & Frequency & Percentage \\
\hline \multirow{2}{*}{ Gender } & Male & 140 & 23.5 \\
& Female & 455 & 76.5 \\
\hline \multirow{2}{*}{ Nationality } & Saudi & 556 & 93.4 \\
& Non-Saudi & 39 & 6.6 \\
\hline \multirow{4}{*}{ Age } & $18-24$ & 368 & 61.8 \\
& $24-30$ & 101 & 17 \\
& $30-36$ & 65 & 10.9 \\
& $36-42$ & 46 & 7.7 \\
& $>42$ & 15 & 2.5 \\
\hline
\end{tabular}




\section{Results}

4.1 Validity and Reliability

Statistical Package for Social Sciences, SPSS $V_{20}$ was used in the statistical analysis of this study. Table 2 shows the estimated values of reliability; Factor Loading, Cronbach's $\alpha$, IC, CR and AVE. The overall valueof Cronbach's $\alpha$ was 0.942 . The sub-scales values of Cronbach's $\alpha$ for each factor of questionnaire were from 0.851 to 0.914 , which means all exceeded the 0.70 level. The result of KMO test was acceptable as the KMO measure of sampling adequacy is 0.925 , which is higher than the critical value 0.50. Results of Bartilett-of-Sphericity test confirmed a significant correlation among variables of each factor $(\mathrm{p}<0.001)$. The estimated range of CR based on actual construct loadings was from 0.798 up to 0.907 , all values above the 0.70 level. AVE values were higher than the cut-off level 0.50 is 0.644 up to 0.904 ; the satisfaction level of DE aspects was 0.775 , curricula 0.663 , instructor 0.747 , procedure 0.651 , customer value 0.904 , equipment 0.609 , reputation 0.644 , WOM 0.806 and e-WOM 0.805. Finally, all these estimated values indicated that reliability is acceptable.

Table 2

Descriptive statistic, validity and reliability estimates

\begin{tabular}{|c|c|c|c|c|c|c|c|}
\hline $\begin{array}{l}\text { Constructs and } \\
\text { Items }\end{array}$ & Mean & SD & $\begin{array}{l}\text { Factors } \\
\text { Loading } \\
\end{array}$ & $\begin{array}{c}\text { CI on } \\
.05 \text { level }\end{array}$ & $\alpha$ & AVE & $\mathrm{CR}$ \\
\hline Satisfaction & & & & & 0.883 & 0.775 & 0.912 \\
\hline $\mathrm{X} 1$ & 3.81 & 1.141 & 0.872 & $\begin{array}{c}3.718 \leq \\
3.902\end{array}$ & & & \\
\hline $\mathrm{X} 2$ & 3.99 & 1.146 & 0.888 & $\begin{array}{c}3.898 \leq \\
4.082\end{array}$ & & & \\
\hline X3 & 4.02 & 1.048 & 0.887 & $\begin{array}{c}3.949 \leq \\
4.091\end{array}$ & & & \\
\hline Curricula (C) & & & & & 0.851 & 0.663 & 0.907 \\
\hline $\mathrm{X} 4$ & 4.02 & 1.048 & 0.864 & $\begin{array}{c}3.949 \leq \\
4.091\end{array}$ & & & \\
\hline $\mathrm{X} 5$ & 3.91 & 0.866 & 0.853 & $\begin{array}{l}3.840 \leq \\
3.980\end{array}$ & & & \\
\hline X6 & 3.90 & 0.934 & 0.852 & $\begin{array}{l}3.825 \leq \\
3.975\end{array}$ & & & \\
\hline $\mathrm{X} 7$ & 3.79 & 0.961 & 0.755 & $\begin{array}{l}3.713 \leq \\
3.867\end{array}$ & & & \\
\hline $\mathrm{X} 8$ & 3.17 & 1.340 & 0.734 & $\begin{array}{c}3.062 \leq \\
3.278\end{array}$ & & & \\
\hline $\begin{array}{c}\text { Instructors (I) } \\
\text { X9 }\end{array}$ & 3.79 & 1.063 & 0.883 & $3.704 \leq$ & 0.852 & 0.747 & 0.855 \\
\hline
\end{tabular}




\begin{tabular}{|c|c|c|c|c|c|c|c|}
\hline \multicolumn{3}{|c|}{ Relevant Correlations among Reputati } & \multicolumn{3}{|c|}{ Dr. Osama Ahmed Abdelkader } & \multicolumn{2}{|c|}{$29 / 4 / 2017$} \\
\hline $\mathrm{X} 10$ & 4.23 & 0.814 & 0.845 & $\begin{array}{c}3.876 \\
4.165 \leq \\
4.296\end{array}$ & & & \\
\hline Procedures $(P)$ & & & & & 0.829 & 0.651 & 0.882 \\
\hline $\mathrm{X} 11$ & 3.96 & 1.009 & 0.843 & $\begin{array}{c}3.874 \leq \\
4.046\end{array}$ & & & \\
\hline $\mathrm{X} 12$ & 3.85 & 1.058 & 0.824 & $\begin{array}{c}3.765 \leq \\
3.935\end{array}$ & & & \\
\hline $\mathrm{X} 13$ & 3.87 & 0.976 & 0.786 & $\begin{array}{c}3.791 \leq \\
3.949\end{array}$ & & & \\
\hline $\mathrm{X} 14$ & 3.39 & 1.300 & 0.772 & $\begin{array}{c}3.285 \leq \\
3.495\end{array}$ & & & \\
\hline $\begin{array}{l}\text { Customer } \\
\text { Value (V) }\end{array}$ & & & & & 0.914 & 0.904 & 0.950 \\
\hline $\mathrm{X} 15$ & 3.74 & 1.027 & 0.951 & $\begin{array}{c}3.667 \leq \\
3.813\end{array}$ & & & \\
\hline $\mathrm{X} 16$ & 3.45 & 1.241 & 0.951 & $\begin{array}{c}3.350 \leq \\
3.550\end{array}$ & & & \\
\hline Equipment (E) & & & & & 0.854 & 0.609 & 0.886 \\
\hline $\mathrm{X} 17$ & 4.02 & 0.909 & 0.868 & $\begin{array}{c}3.947 \leq \\
4.093\end{array}$ & & & \\
\hline $\mathrm{X} 18$ & 3.99 & 0.889 & 0.791 & $\begin{array}{c}3.918 \leq \\
4.062\end{array}$ & & & \\
\hline $\mathrm{X} 19$ & 3.64 & 1.112 & 0.776 & $\begin{array}{c}3.551 \leq \\
3.730\end{array}$ & & & \\
\hline $\mathrm{X} 20$ & 3.67 & 1.077 & 0.741 & $\begin{array}{c}3.583 \leq \\
3.757\end{array}$ & & & \\
\hline $\mathrm{X} 21$ & 3.49 & 1.223 & 0.716 & $\begin{array}{c}3.392 \leq \\
3.559\end{array}$ & & & \\
\hline Reputation: & & & & & 0.881 & 0.644 & 0.782 \\
\hline $\mathrm{X} 22$ & 4.02 & 1.048 & 0.889 & $\begin{array}{c}3.936 \leq \\
4.104\end{array}$ & & & \\
\hline $\mathrm{X} 23$ & 4.10 & 0.962 & 0.706 & $\begin{array}{c}4.023 \leq \\
4.178\end{array}$ & & & \\
\hline WOM: & & & & & 0.852 & 0.806 & 0.892 \\
\hline $\mathrm{X} 24$ & 4.12 & 0.914 & 0.911 & $\begin{array}{c}4.046 \leq \\
4.194\end{array}$ & & & \\
\hline $\mathrm{X} 25$ & 4.21 & 0.844 & 0.884 & $\begin{array}{c}4.143 \leq \\
4.278\end{array}$ & & & \\
\hline$e-W O M$ & & & & & 0.851 & 0.805 & 0.892 \\
\hline $\mathrm{X} 26$ & 3.78 & 1.096 & 0.910 & $\begin{array}{c}3.692 \leq \\
3.868\end{array}$ & & & \\
\hline $\mathrm{X} 27$ & 3.78 & 1.070 & 0.884 & $3.708 \leq$ & & & \\
\hline
\end{tabular}


4.2 Hypotheses Test Results:

Fig. 1 shows the results of the hypotheses test of model variables, which including the following:

- $H_{1}$ Test: Gender $\rightarrow$ Satisfaction

Tests of Mann-Whitney and Wilcoxon showed significant differences in satisfaction among cases according to their gender, $(\mathrm{p}<0.001)$, the mean rank of males being more than females. The effect that gender has on satisfaction was measured by Glass-Rank-Biserial-Correlation 0.27, showing a weak effect but significant.

- $\mathrm{H}_{2}$ Test: Age $\rightarrow$ Satisfaction

Test of Kruskal-Willis showed significant differences in satisfaction among cases according to their age, $(\mathrm{p}<0.001)$, the mean rank of older cases being more satisfied than the younger. The effect that gender had on satisfaction was $(\theta=0.10)$, showing a weak but significant effect.

- $\mathrm{H}_{3}$ Test: Nationality $\rightarrow$ Satisfaction

Tests of Mann-Whitney and Wilcoxon showed non-significant differences in satisfaction among cases according to their nationality, $(\mathrm{p}>0.05)$.

- H4 Test: Key elements of service (5 Items) + Reputation $\rightarrow$ Satisfaction

Multi Regression Analysis showed significant correlations with satisfaction and reputation, customer value, curricula and equipment $\left(\mathrm{R}=0.712, \mathrm{R}^{2}=\right.$ 0.507 and Adjusted $\mathrm{R}^{2}=0.503, \mathrm{p}<0.001$ ). No significant correlations were indicated for the other elements, instructors and procedures.

- $H_{5}$ Test: Reputation $\rightarrow$ Satisfaction

Tests of Kendall's tau-b ( $\mathrm{V}=0.563, \mathrm{p}<0.001)$, Kendall's tau-c $(\mathrm{V}=0.481, \mathrm{P}$ $<0.001)$ and Gamma $(\mathrm{V}=687, \mathrm{p}<0.001)$ showed a significant correlation (average) between reputation and satisfaction.

- H6 Test: Satisfaction $\rightarrow$ WOM

Tests of Kendall's tau-b $(0.588, \mathrm{p}<0.001)$, Kendall's tau-c $(\mathrm{V}=0.481, \mathrm{P}<$ $0.001)$ and Gamma $(\mathrm{V}=739, \mathrm{p}<0.001)$ showed a significant correlation between satisfaction and WOM.

- $H_{7}$ Test: $W O M \rightarrow$ Reputation

Tests of Kendall's tau-b $(\mathrm{V}=0.533, \mathrm{p}<0.001)$, Kendall's tau-c $(\mathrm{V}=0.410, \mathrm{P}$ $<0.001)$ and Gamma $(\mathrm{V}=706, \mathrm{p}<0.001)$ showed a significant correlation between WOM and reputation.

- $H_{8}$ Test: Satisfaction $\rightarrow e-W O M$ 
Tests of Kendall's tau-b (V=0.408, $\mathrm{p}<0.001)$, Kendall's tau-c $(\mathrm{V}=0.341, \mathrm{P}$ $<0.001)$ and Gamma $(\mathrm{V}=515, \mathrm{p}<0.001)$ showed a significant correlation between satisfaction and e-WOM.

- $H_{9}$ Test: $e-W O M \rightarrow$ Reputation

Tests of Kendall's tau-b $(\mathrm{V}=0.400, \mathrm{p}<0.001)$, Kendall's tau-c $(\mathrm{V}=0.315, \mathrm{P}$ $<0.001)$ and Gamma $(\mathrm{V}=541, \mathrm{p}<0.001)$ showed a significant correlation between e-WOM and reputation.

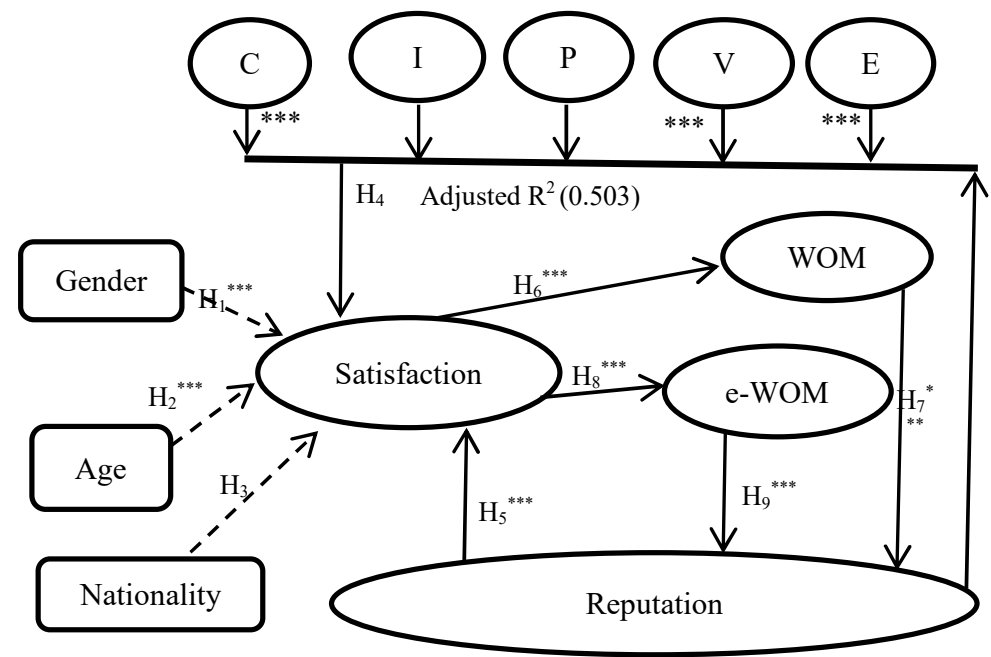

Fig. 1. Hypotheses Structure Results of Model

\section{Discussion and Conclusion:}

This study aimed to present a proposed model for academics and practitioners to support them in building better understand the preferences of DE students. Table 4 summarizes the hypotheses results, which are grouped as follows:

First, the study indicated that males are significantly more satisfiedthan females. Theseresults are consistent with the findings of Poellhuber et al., (2013), Oda, (2012), Anthony, (2012), Mulki, and Jaramillo, (2011) and Tu, (2011), but it is not consistent with (Cho and Kim, 2013). Also, older students are significantly more satisfied than younger ones. These findings of Poellhuber et al., (2013), Mulki, and Jaramillo, (2011) and Oda, (2012) were supported in this research, but it is not consistent with (Oda, 2012). These 
findings suggest that institutions using DE should take into consideration the possibility of lower satisfaction among users who are female or young. There are no significant differences in satisfaction according to nationality between Saudis and other Arabian nationalities, which is not consistent with many previousliterature indicating significant differences according to crossculture. An explanationfor this difference in finding could be the fact that Saudis and the other 22 Arabian nationalities share the same culture and language. However, administrators of DE programs should be careful when they aim to teach students from other cultures.

Second, thereare significant correlations between satisfaction and reputation. This result is consistent with the results of Saeidi et al, (2015), Sengupta et al, (2015), Sultan and Wong, (2012), Mulki, and Jaramillo, (2011) and Cretu and Brodie, (2007).The study indicated asignificant influence ofWOM and e-WOMon satisfaction and reputation. As similar findings were supported by Wu, 2011; Liang and Zhang, (2012), Mulki, and Jaramillo, (2011), Ganguli, and Roy, (2011), Abdelhameed and Alqasaby, (2012). The presented model indicated the significant influences of reputation, curricula, equipment and customer value on satisfaction.Reputation has the most effect. There was no significantinfluence of instructors and process.

Table 4: Results of Hypotheses Test

\begin{tabular}{|l|c|}
\hline \multicolumn{1}{|c|}{ The Variables of Hypotheses } & Supported? \\
\hline $\mathrm{H}_{1}:$ Gender $\rightarrow$ Satisfaction & Yes**** \\
\hline $\mathrm{H}_{2}:$ Age $\rightarrow$ Satisfaction & Yes *** \\
\hline $\mathrm{H}_{3}:$ Nationality $\rightarrow$ Satisfaction & No \\
\hline $\begin{array}{l}\mathrm{H}_{4}: \text { Curricula, instructors, procedures, customer value, equipment and } \\
\text { reputation with satisfaction }\end{array}$ & Yes ***a \\
\hline $\mathrm{H}_{5}:$ Reputation $\rightarrow$ Satisfaction & Yes *** \\
\hline $\mathrm{H}_{6}:$ Satisfaction $\rightarrow$ WOM & Yes *** \\
\hline $\mathrm{H}_{7}:$ WOM $\rightarrow$ Reputation & Yes *** \\
\hline $\mathrm{H}_{8}:$ Satisfaction $\rightarrow$ e-WOM & Yes $* * *$ \\
\hline $\mathrm{H}_{9}:$ e-WOM $\rightarrow$ Reputation & Yes $* * *$ \\
\hline
\end{tabular}

$* * * \mathrm{p}<0.001$, (a) The correlations of instructors and procedures were non-significant.

Finally, the findings of this study leadpractitioners of DE programs to give special interest to the significant factors that affect student satisfaction. The effect size and explaining ability of this model could be maximized through future research. Further, these findings could be taken into consideration by other universities, countries and cultures while offering DE programs. 


\section{References:}

Abdelhameed, T., Alqasaby, M. (2012). "The Impact of WOM to realize of Health Services, Egyptian Periodical of Commercial Studies, 36(2), pp. 361-386.

Abrantes, J., Seabra, C.,Lages, C. and Jayawardhena, C. (2013), Drivers of in-group and out-of-group electronic word-ofmouth (eWOM), European Journal of Marketing, 47(7), pp. 1067-1088.

Aldulimi, O. Y. (2014). "The Impact of Word of Mouth on Purchase Decisions A Study of An Opinion Sample of Some Restraints in The City of Mosul", Tanmit Al-rafidain, 36(115), pp 217-236.

Ali, H. A. (2010). "The Role of WOM in the Customer's Choice for Physician", Egyptian Periodical of Commercial Studies, 34(1), pp. 585-630.

Amin, M., Isa, Z. and Fontaine, R. (2013), Islamic banks Contrasting the drivers of customer satisfaction on image, trust, and loyalty of Muslim and non-Muslim customers in Malaysia, International Journal of Bank Marketing, 31(2), pp. 79-97.

Anthony, K. (2012), "Analyzing the influences of course design and gender on onlineparticipation", Online Journal of Distance Education Administration, 15(3), available at: www.westga.edu/,distance/ojdla/fall153/anthony153.html.

Argan, M. (2016). Investigating word-of-mouth (WOM) factors influencing patients' physician choice and satisfaction. International Journal of Medical Research \& Health Sciences, 5(1), 191-198.

Bachleda, C., \&Berrada-Fathi, B. (2016). Is negative eWOM more influential than negative pWOM?Journal of Service Theory and Practice, 26(1), 109-132.

Barak, M., \&Levenberg, A. (2016). Flexible thinking in learning: An individual differences measure for learning in technologyenhanced environments. Computers \& Education, 99, 39-52.

Berberoğlu, B. (2015). Open and Distance Education Programs of Anadolu University Since the Establishment. Procedia-Social and Behavioral Sciences, 174, 3358-3365. 
Biong, H. (2013), Choice of subcontractor in markets with asymmetric information: reputation and price effects, Journal of Business \& Industrial Marketing, 28(1), pp. 60-71.

Bower, M., Dalgarno, B., Kennedy, G. E., Lee, M. J., \& Kenney, J. (2015). Design and implementation factors in blended synchronous learning environments: Outcomes from a crosscase analysis. Computers \& Education, 86, 1-17.

Brinson, J. R. (2015). Learning outcome achievement in nontraditional (virtual and remote) versus traditional (hands-on) laboratories: A review of the empirical research. Computers \& Education, 87, 218-237.

Casidy, R., \&Wymer, W. (2015). The impact of brand strength on satisfaction, loyalty and WOM: An empirical examination in the higher education sector. Journal of Brand Management, 22(2), 117-135.

Celik, B., \&Uzunboylu, H. (2015). High School Students' Attitudes towards Distance Education: Comparative Study. ProcediaSocial and Behavioral Sciences, 197, 292-297.

Chang, A., Chiang, H. and Han, T. (2012), A multilevel investigation of relationships among brand-centered HRM, brand psychological ownership, brand citizenship behaviors, and customer satisfaction, European Journal of Marketing, 46(5), pp. 626-662.

Chang, H. H., \& Wu, L. H. (2014). An examination of negative eWOM adoption: Brand commitment as a moderator. Decision Support Systems, 59, 206-218.

Chen, J., Teng, L., Yu, Y., \& Yu, X. (2016). The effect of online information sources on purchase intentions between consumers with high and low susceptibility to informational influence. Journal of Business Research, 69(2), 467-475.

Chen, Y., Yang, S., \& Wang, Z. (2015). Service cooperation and marketing strategies of infomediary and online retailer with eWOM effect. Information Technology and Management, 1-10.

Cho, M. H., \& Kim, B. J. (2013). Students' self-regulation for interaction with others in online learning environments. The Internet and Higher Education, 17, 69-75. 
Christodoulides, G., Michaelidou, N. and Argyriou, E. (2012), Crossnational differences in e-WOM influence, European Journal of Marketing, 46(11), pp. 1689-1707.

Cretu, A. E., \& Brodie, R. J. (2007). The influence of brand image and company reputation where manufacturers market to small firms: A customer value perspective. Industrial Marketing Management, 36(2), 230-240.

de' Hart, K. L., Chetty, Y. B., \& Archer, E. (2015). Uptake of OER by staff in distance education in South Africa. The International Review of Research in Open and Distributed Learning, 16(2).

Edward, M. and Sahadev, S. (2011), Role of switching costs in the service quality, perceived value, customer satisfaction and customer retention linkage, Asia Pacific Journal of Marketing and Logistics, 23(3), pp. 327-345.

Erkan, I., \& Evans, C. (2016). The influence of eWOM in social media on consumers' purchase intentions: An extended approach to information adoption. Computers in Human Behavior, 61, 47-55.

Evanschitzky, H., Sharma, A. and Prykop, C. (2012), The role of the sales employee in securing customer satisfaction, European Journal of Marketing, 46(3/4), pp. 489-508.

Ganguli, S. and Roy, S. (2011), Generic technology-based service quality dimensions in banking Impact on customer satisfaction and loyalty, International Journal of Bank Marketing, 29(2), pp. 168-189.

Gura u, C. (2013), Developing an environmental corporate reputation on the internet, Marketing Intelligence \& Planning, 31(5), pp. 522-537.

Holmberg, B. (2005). "The evolution, principles and practices of distance education", Universität Oldenburg (ASF), ISBN 38142-0933-8, p. 13.

Hone, K. S., \& El Said, G. R. (2016). Exploring the factors affecting MOOC retention: A survey study. Computers \& Education, 98, 157-168. 
Huang, M., Cai, F., Tsang, A. and Zhou, N. (2011), Making your online voice loud: the critical role of WOM information, European Journal of Marketing, 45(7), pp. 1277-1297.

Joksimović, S., Gašević, D., Loughin, T. M., Kovanović, V., \&Hatala, M. (2015). Learning at distance: Effects of interaction traces on academic achievement. Computers \& Education, 87, 204217.

Kietzmann, J., Canhoto, A. (2013). "Bittersweet! Understanding and Managing Electronic Word of Mouth", Journal of Public Affairs, 13(2), pp 146-159.

Kim, J. and Lennon, S. (2013), Effects of reputation and website quality on online consumers' emotion, perceived risk and purchase intention Based on the stimulus-organism-response Model, Journal of Research in Interactive Marketing, 7(1), pp. 33-56.

Koper, R. (2015). How do students want to learn in online distance education? Profiling student preferences. The International Review of Research in Open and Distributed Learning, 16(1).

Korving, H., Hernández, M., \& De Groot, E. (2016). Look at me and pay attention! A study on the relation between visibility and attention in web-lectures. Computers \& Education, 94, 151-161.

Latypov, N. R., \&Sabirova, D. R. (2016). Exploring Motivation Patterns in the English-Medium Academic Environment. International Journal of Humanities and Cultural Studies (IJHCS) ISSN 2356-5926, 1(1), 320-326.

Lang, B.; Lawson, R. (2013). "Dissecting Word-of-Mouth's Effectiveness and How to Use It as a Pro-Consumer Tool", Journal of Nonprofit \& Public Sector Marketing, 25(4), pp 374-399.

Liang, R. and Zhang, J. (2012), The effect of service interaction orientation on customer satisfaction and behavioral intention the moderating effect of dining frequency, Asia Pacific Journal of Marketing and Logistics, 24(1), pp. 153-170.

Lin, T., Lu, K. and Wu, J. (2012), The effects of visual information in eWOM communication, Journal of Research in Interactive Marketing, 6(1), pp. 7-26. 
Lo'pez, M. and Sicilia, M. (2013), Testing competitive communication strategies How WOM marketing contributes to new product adoption, European Journal of Marketing, 47(7), pp. 1089-1114.

Lo'pez, X., Valenzuela, J., Nussbaum, M., \& Tsai, C. C. (2015). Some recommendations for the reporting of quantitative studies. Computers \& Education, 91(C), 106-110.

Lorenzo-Molo, M. C. F. (2007). Understanding the reputation and image of the Philippine public relations industry. Public Relations Review, 33(1), 58-67.

Malganova, I., \&Rahkimova, A. (2015). The Usage of Distance Education Practice of the World Leading Universities in Russian Multiethnic Region. Procedia-Social and Behavioral Sciences, 191, 2622-2625.

Mbati, L., \&Minnaar, A. (2015). Guidelines towards the facilitation of interactive online learning programs in higher education. The International Review of Research in Open and Distributed Learning, 16(2).

Men, L. R. (2012). CEO credibility, perceived organizational reputation, and employee engagement. Public Relations Review, 38(1), 171-173.

Merhi, M. I. (2015). Factors influencing higher education students to adopt podcast: an empirical study. Computers \& Education, 83, 32-43.

Mulki, J. and Jaramillo, F. (2011), Ethical reputation and value received: customer perceptions, International Journal of Bank Marketing, 29(5), pp. 358-372.

Mysen, T. and Svensson, G. and Payan, J. (2011), Causes and outcomes of satisfaction in business relationships, Marketing Intelligence \& Planning, 29(2), pp. 123-140.

O'Cass, A. and Ngo, L. (2011), Achieving customer satisfaction in services firms via branding capability and customer empowerment, Journal of Services Marketing, 25(7), pp. 489496.

Oda, E. S. (2012). "Relationship Effectiveness between Electronic Services 
Reputation Study on a Sample of Jordanian Private Universities", Master Thesis, Middle East University.

Van Rooyen, A. (2015). Distance education accounting students' perceptions of social media integration. Procedia-Social and Behavioral Sciences, 176, 444-450.

Poellhuber, B., Anderson, T., Racette, N., \& Upton, L. (2013). Distance students' readiness for and interest in collaboration and social media, Interactive Technology and Smart Education, 10(1), 63-78.

Saeidi, S. P., Sofian, S., Saeidi, P., Saeidi, S. P., \&Saaeidi, S. A. (2015). How does corporate social responsibility contribute to firm financial performance? The mediating role of competitive advantage, reputation, and customer satisfaction. Journal of Business Research, 68(2), 341-350.

San-Martín, S., Prodanova, J., \& Jiménez, N. (2015). The impact of age in the generation of satisfaction and WOM in mobile shopping. Journal of Retailing and Consumer Services, 23, 1-8.

Semradova, I., \&Hubackova, S. (2016). Teacher Responsibility in Distance Education. Procedia-Social and Behavioral Sciences, 217, 544-550.

Sengupta, A. S., Balaji, M. S., \& Krishnan, B. C. (2015). How customers cope with service failure? A study of brand reputation and customer satisfaction. Journal of Business Research, 68(3), 665-674.

Shim, K., \& Yang, S. U. (2015). The effect of bad reputation: The occurrence of crisis, corporate social responsibility, and perceptions of hypocrisy and attitudes toward a company. Public Relations Review.

Sung, Y. T., Chang, K. E., \& Liu, T. C. (2016). The effects of integrating mobile devices with teaching and learning on students' learning performance: A meta-analysis and research synthesis. Computers \& Education, 94, 252-275.

Shin, J. K., Park, M. S., \& Moon, M. K. (2015). Do Eco-friendly VMD and Store Reputation Increase Satisfaction of Retail Customers? Psychology \& Marketing, 32(12), 1148-1157.

Su, L., Swanson, S. R., Chinchanachokchai, S., Hsu, M. K., \& Chen, $X$. (2016). Reputation and intentions: The role of satisfaction, 
identification, and commitment. Journal of Business Research, 69(9), 3261-3269.

Su, L., Swanson, S. R., \& Chen, X. (2015). Social responsibility and reputation influences on the intentions of Chinese Huitang Village tourists: Mediating effects of satisfaction with lodging providers. International Journal of Contemporary Hospitality Management, 27(8), 1750-1771.

Tournois, L. (2015). Does the value manufacturers (brands) create translate into enhanced reputation? A multi-sector examination of the value-satisfaction-loyalty-reputation chain. Journal of Retailing and Consumer Services, 26, 83-96.

Tu, C.H., Yen, C.J. and Blocher, M. (2011), "A study of the relationship between gender and online social presence", International Journal of Online Pedagogy and Course Design (IJOPCD), 1(3), pp. 33-49.

Wu, L. (2011), Satisfaction, inertia, and customer loyalty in the varying levels of the zone of tolerance and alternative attractiveness, Journal of Services Marketing, 25(5), pp. 310322.

Yang, J., Kim, W., Amblee, N. and Jeong, J. (2012), The heterogeneous effect of WOM on product sales: why the effect of WOM valence is mixed?European Journal of Marketing, 46(11), pp. 1523-1538.

Yan, Q., Wu, S., Wang, L., Wu, P., Chen, H., \& Wei, G. (2016). EWOM from e-commerce websites and social media: Which will consumers adopt?Electronic Commerce Research and Applications, 17, 62-73.

Yang, S. H. (2016). Conceptualizing effective feedback practice through an online community of inquiry. Computers \& Education, 94, 162-177.

York, C. S., Yamagata-Lynch, L. C., \&Smaldino, S. E. (2016). Adult reflection in a graduate-level online distance education course. Reflective Practice, 17(1), 40-58. 